\section{THE PALISADED ENCLOSURE (AREAA)}

This area represents the final prehistoric period at Blackford with radiocarbon dates generally indicating an Early Iron Age (EIA) period of occupation, although a Middle Bronze Age (MBA) date was returned from a pit within Structure 1A and a pit outside the Iron Age palisaded enclosure. The excavation area covered $3,803 \mathrm{~m}^{2}$, within which were an elliptical palisaded settlement containing two large post-built circular structures; two four-post structures; and numerous pits both within and outside the palisade (Illus 51). The settlement occupied the top of a drumlin and commanded uninterrupted views of the surrounding landscape as well as the other Blackford sites. All the features were cut into the subsoil of yellow-orange sand and gravel.

\subsection{The palisade}

The palisade trench was examined by the excavation of a series of slots through it (Illus 52), alternately excavated in plan and via longitudinal sections, with the aim of identifying post holes within its fill. Post holes were, however, only identified in the longitudinal sections (eg Slot $5 \mathrm{~N}$ Illus 51).



Illus 51 Plan of Area A 


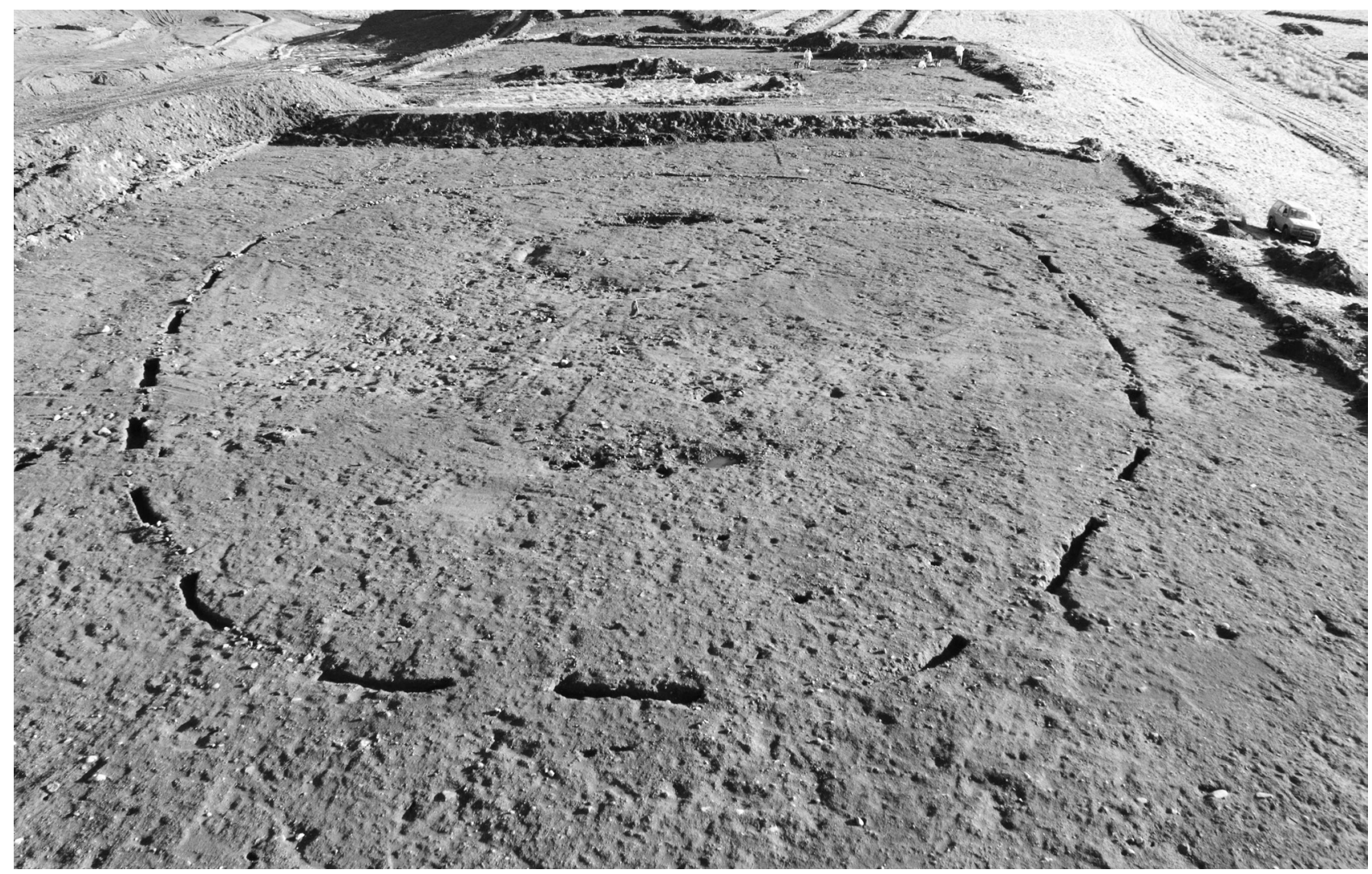

Illus 52 Aerial view of Area A

The cut of the palisade (058) defined an elliptical enclosure of maximum dimensions of $c 52 \mathrm{~m}$ along its north-west/south-east major axis and $36 \mathrm{~m}$ along its north-east/south-west minor axis. The palisade trench was $c 0.45 \mathrm{~m}$ wide by $0.3 \mathrm{~m}$ deep, with a circumference of $c 140 \mathrm{~m}$. The trench was filled with firmly compacted reddish sand and gravel (059) and packed with angular stones (157) set edgewise. The upper fill of the palisade trench (156) was a discontinuous layer of loosely compacted dark brown to black silt, also containing sub-rounded cobbles and similar to the overlying topsoil (001), possibly suggesting that the palisade had rotted in situ.

Seven pits interpreted as post holes were recorded within the cut of the palisade (Table 19), the majority being found on its northern side and mostly identified in section. The depth of the palisade cut was shallower on its southern side, probably resulting from differential erosion, as the southern half of the palisade occupied a position nearer the break of slope than did the northern half, and consequently had suffered greater attrition. The post holes were seen to be neither evenly spaced nor contiguous.
The evidence of the surviving post holes within the trench suggests that round wooden posts were used in the construction of the palisade, and the presence of angular stones, set edgewise, suggests the use of packing stones. One interpretation is that the palisade was formed from a contiguous series of planks supported by intermittent upright posts.

Table 19 Post-hole dimensions within palisade

\begin{tabular}{cccc} 
PH/Cut & Width & Length & Depth \\
\hline 060 & 0.28 & 0.30 & 0.24 \\
\hline 073 & 0.20 & 0.20 & 0.25 \\
\hline 074 & 0.20 & 0.26 & 0.40 \\
\hline 138 & 0.25 & 0.20 & 0.40 \\
\hline 140 & 0.15 & 0.20 & 0.40 \\
\hline 151 & 0.25 & 0.30 & 0.50 \\
\hline 153 & 0.20 & 0.20 & 0.30 \\
\hline 165 & 0.22 & 0.36 & 0.16 \\
\hline 234 & 0.35 & 0.39 & 0.17 \\
\hline Average & 0.23 & 0.26 & 0.31
\end{tabular}


With the exception of Post Hole 074, no surviving wood or charcoal was recovered from the putative post holes. If these pits functioned as post holes then the wooden posts appear not to have burnt in situ; they may either have decayed or were removed. Post Hole 074 contained fragments of oak charcoal, as did the palisade foundation trench, however it cannot be said for certain where this burnt material originally derived from.

The dimensions of the post holes are given in Table 19. The average diameter of the holes, and by extension the posts themselves, was $0.24 \mathrm{~m}$. The post holes were steep-sided and tapered towards their concave bases, suggesting that the post had a similar profile. Five other posts (eg 258 Illus $53 \mathrm{~b}$ ) were cut into the side of the palisade (not visible in plan). One possible explanation for this is that they represent repairs to the palisade after its construction.

The palisade had two points of access, both $c 2 \mathrm{~m}$ wide, and defined by opposing terminals, one to the north-west where the cut of post holes could be seen in section and plan (060 and 165), and the other to the south-east, where no post holes were recorded in section, although the terminals of the palisade show a bulge typical of post holes in plan. Two large sub-angular boulders of length $0.6-0.8 \mathrm{~m}$ framed the south-east entrance externally, although whether these were placed there deliberately is a matter for conjecture.

\subsection{Structure $1 \mathrm{~A}$}

The eastern of the two circular structures was a post-built roundhouse with a pair of annexes on its south and south-east sides (Illus 54). Its diameter was $12 \mathrm{~m} \mathrm{~N}-\mathrm{S}$ excluding the southern annex and $14 \mathrm{~m}$ including it. The south-east-facing entrance was defined by a break in the post hole ring. The interior of the house was flat and contained several features. There was an external pit (422) adjacent to the south-east quadrant of the house, bounded on two sides by Gullies 481 and 497, with a further section of truncated gully on its northern side (501).

The ring of 52 post holes, marking the wall of the structure, ranged in size from $0.14 \mathrm{~m}$ by $0.17 \mathrm{~m}$ by $0.07 \mathrm{~m}$ deep to $0.4 \mathrm{~m}$ by $0.4 \mathrm{~m}$ by $0.1 \mathrm{~m}$. They were circular or oval in form and generally had concave bases and were filled with loosely compacted sandy silt. There was evidence of paired post holes, interpreted as replacements, with Post Holes 413/415, 485/477 and 343/341, and possibly, because of their proximity, 373/371 and $331 / 336 / 334$. On the south-east side of the house and running along the inner edge of the external pit (422), the gully, 481, was interpreted as a foundation slot for a short section of wall replacing the post hole ring.

The entrance to the main building was defined by four opposing post holes (425, 415, 561 and 477), and a central pit (420) ranging in size from $0.28 \mathrm{~m}$

$\mathrm{E}$

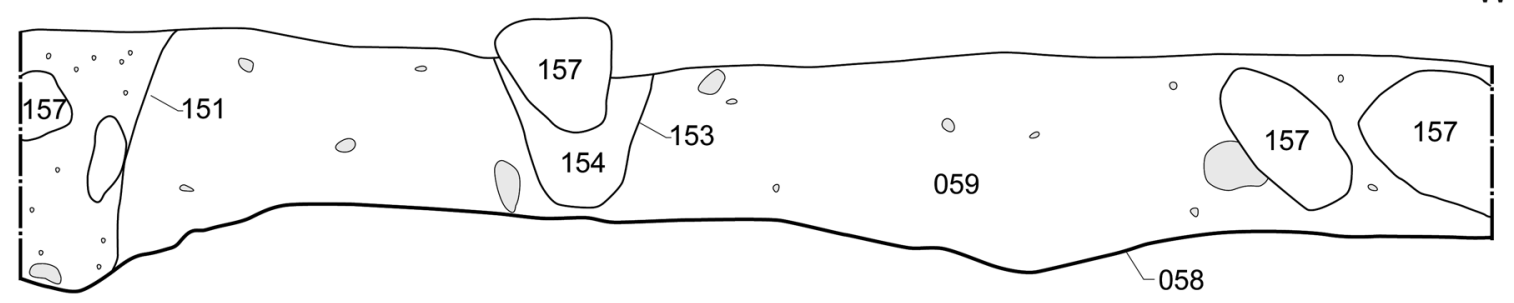

(53b) $\mathrm{N}$
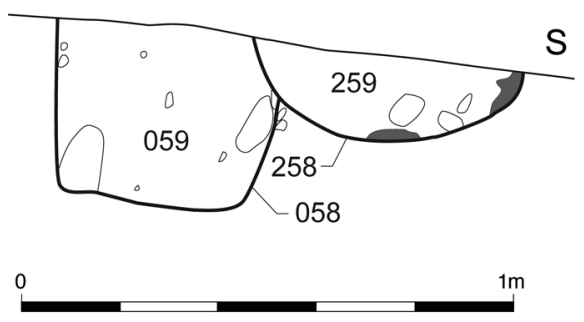

Illus 53 Selected sections of the palisade 


\section{Str 2A}

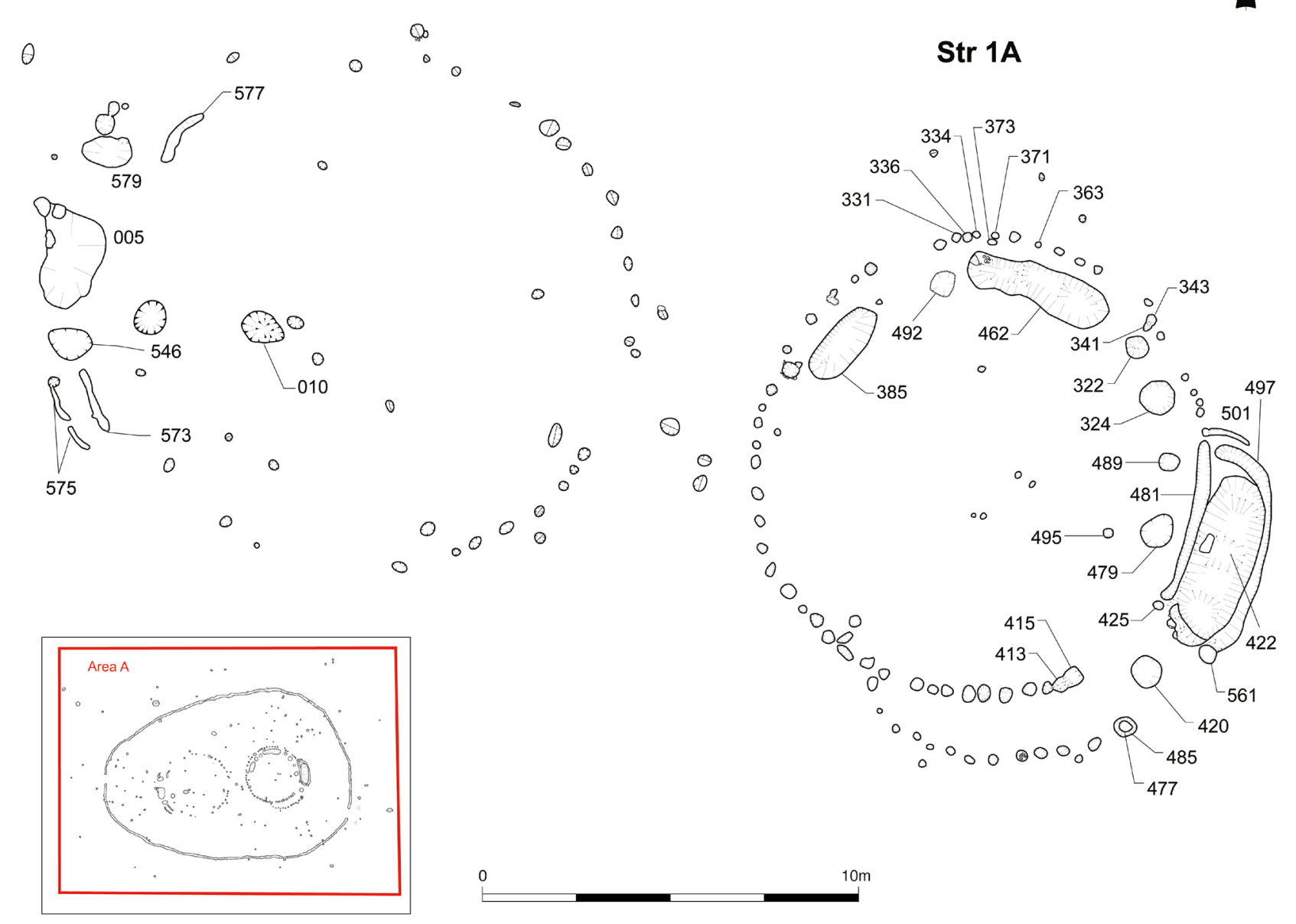

Illus 54 Plan of Area A, Structures $1 \mathrm{~A}$ and $2 \mathrm{~A}$

by $0.28 \mathrm{~m}$ by $0.16 \mathrm{~m}$ deep to $0.75 \mathrm{~m}$ by $0.75 \mathrm{~m}$ by $0.15 \mathrm{~m}$ deep. The function of Pit 420 could not be determined. The entrance was $3 \mathrm{~m}$ wide and faced south-east, and was aligned with the south-east entrance of the palisade.

The two annexes were accessed from the porch. The 15 post holes forming the annex to the south-west of the entrance were similar in form to those of the main post ring and ranged in size from $0.15 \mathrm{~m}$ by $0.15 \mathrm{~m}$ by $0.05 \mathrm{~m}$ deep to $0.4 \mathrm{~m}$ by $0.6 \mathrm{~m}$ by $0.12 \mathrm{~m}$ deep and were filled with loosely compacted sandy silt similar in nature to the fills of the post holes forming the outer wall of the structure. The annex to the north-east of the entrance was made up of several features, notably a large pit (422) $(4.6 \mathrm{~m}$ by $1.6 \mathrm{~m}$ by $0.9 \mathrm{~m}$ deep; Illus $55 \mathrm{a}$ ). The pit was filled with three deposits: the upper deposit (423) was a loosely compacted dark brown sandy silt containing sub-rounded cobbles (424), the secondary fill was also a loosely compacted sandy silt but was more orange in colour, as was the primary fill (488). Both appeared to derive from burnt material, an observation supported by the soil micromorphology analysis (see Section 10.7.4). Pit 422 was bounded on three sides by two shallow gullies, both filled with loose mid-brown to grey sandy silt. The inner gully, 481 , measured $3.5 \mathrm{~m}$ by $0.32 \mathrm{~m}$ by $0.2 \mathrm{~m}$ deep, and appeared to be a continuation of the main post ring. The outer gully, 497 , measured $6.15 \mathrm{~m}$ by $0.4 \mathrm{~m}$ by $0.14 \mathrm{~m}$. This gully has been interpreted as a trench for a timber wall bounding the exterior of Pit 422, of which the sub-angular to sub-rounded cobbles (424) found within Pit 422 may represent packing. A further gully, 501, was present to the north of Gully 497 and measured $1.4 \mathrm{~m}$ by $0.12 \mathrm{~m}$ by $0.05 \mathrm{~m}$ deep, the function of which could not be 
determined. No evidence for a roof was identified on the annex to the south-west of the entrance, but as it formed an extension to the porch it seems likely that both annexes would have been covered.

Fourteen internal house features were present. With the exception of 462 , all were filled with single deposits of loose sandy silt varying in colour from light grey to brown, none of which contained burnt material suggestive of a hearth. There was an arc of four sub-rounded pits on the north-east side of the house (322, 324 (Illus 55b), 489 and 479) with dimensions ranging in size from $0.5 \mathrm{~m}$ by $0.68 \mathrm{~m}$ by $0.12 \mathrm{~m}$ deep to $1 \mathrm{~m}$ by $1 \mathrm{~m}$ by $0.11 \mathrm{~m}$ deep. Two other large pits were found, one on the north-west side of the house (385) measuring $2.2 \mathrm{~m}$ by $1 \mathrm{~m}$ by $0.21 \mathrm{~m}$ deep, and one on the north side of the house (462 Illus 55c) measuring $3.8 \mathrm{~m}$ by $1.2 \mathrm{~m}$ by $0.45 \mathrm{~m}$ deep. Pit 462 contained two fills, 463 and 464, both containing burnt animal faeces, possibly derived from burnt animal bedding, or from dried fuel (see soil micromorphology at Section 10.7.4 below). A hollow in the north-west part of the house, 492, contained the remains of a possible post-pad (491) fabricated from large flat stones. The other nine internal features were scattered throughout the house and ranged in size from $0.12 \mathrm{~m}$ by $0.12 \mathrm{~m}$ by $0.05 \mathrm{~m}$, to $0.3 \mathrm{~m}$ by $0.5 \mathrm{~m}$ by $0.1 \mathrm{~m}$.

\subsection{Structure 2A}

The western circular structure was post-built, $14 \mathrm{~m}$ in diameter, and considerably more truncated than Structure 1A (Illus 54). It was principally defined by an arc of post holes on its eastern side, forming the wall of the structure, with a large pit on its northwest side. There were 14 internal features. Due to truncation, the position of the entrance could not be determined with certainty. However, a gap between Features 005 and 579 could represent an entrance that was aligned with the north-west entrance of the palisade.

There were 24 circular and oval post holes in a ring defining the house, with dimensions that ranged from $0.1 \mathrm{~m}$ by $0.1 \mathrm{~m}$ by $0.12 \mathrm{~m}$ deep to $0.45 \mathrm{~m}$ by $0.50 \mathrm{~m}$ by $0.25 \mathrm{~m}$. Two linear features, 573 and 577 , may represent the truncated remains of foundation slots associated with this post ring.

There was an arc of pits, 546, 005 and 579, on the western side of the structure; the largest (005) measured $5.6 \mathrm{~m}$ by $2 \mathrm{~m}$ by $0.45 \mathrm{~m}$ deep. There were 16 other internal features ranging in size

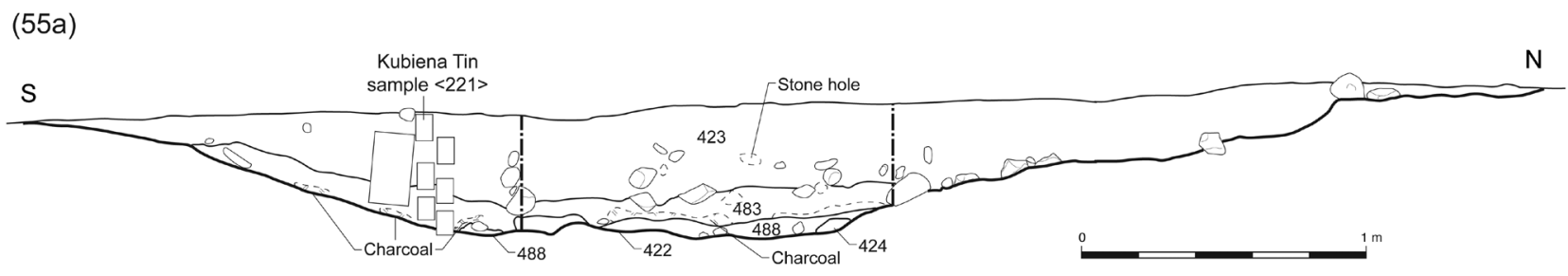

(55b)

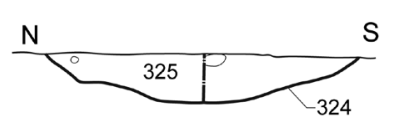

(55d)

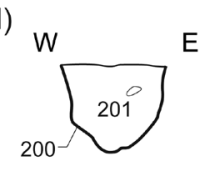

(55e)

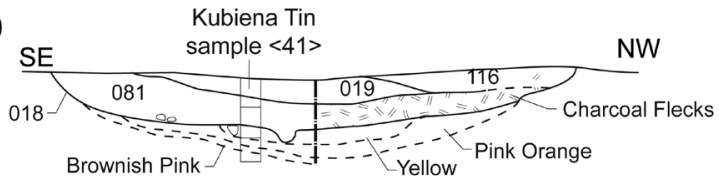

(55c)

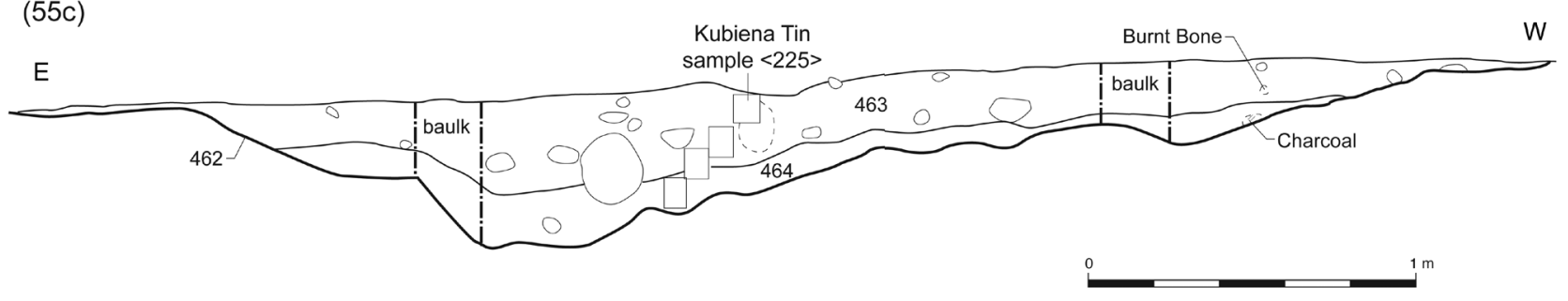

Illus 55 Selected sections of Structures 1A, 4A and external Pit 018, Area A 
from $0.18 \mathrm{~m}$ by $0.21 \mathrm{~m}$ by $0.05 \mathrm{~m}$ deep to $1.4 \mathrm{~m}$ by $1.3 \mathrm{~m}$ by $6.4 \mathrm{~m}$. Three of these features were linear (577, 573 and 575), the rest were sub-circular pits. Although the size and location of Pit 010 suggested a hearth, on excavation it produced no evidence of burnt in-situ deposits or discoloration of the soil indicative of repeated burning, rather the fill contained sub-angular stones possibly used as a packing material. It is possible that Pits 579, 005, 546 and Linear Features 575, 573 and 577 represent an annex similar to that seen in Structure $1 \mathrm{~A}$, effectively showing that Structure $2 \mathrm{~A}$ is a mirror image of Structure 1A; both accompanied by four-post structures (see below) and associated with a respective entrance to the palisade.

\subsection{Structures $3 \mathrm{~A}$ and $4 \mathrm{~A}$}

These two groups of features were thought to be rectangular structures based on the similarities in their respective post holes in size, form and fills. A similar example $(2 \mathrm{~F})$ has been recorded elsewhere (see Section 8.2).

The five post holes of Structure 3A (045, 003, $106,120,122$ Illus 51) were each sub-circular in plan and were approximately $0.3-0.35 \mathrm{~m}$ in diameter and $0.27-0.34 \mathrm{~m}$ deep. They each contained a single fill of loosely compacted dark brown silt. The four post holes of Structure 4A (191, 198, 200 (Illus $55 \mathrm{~d}), 195)$ were circular in plan and varied between $0.3-0.4 \mathrm{~m}$ in diameter and $0.2-0.28 \mathrm{~m}$ deep. They were all filled with a single deposit of dark greyishbrown sandy silt. Overall, the structures measured a maximum of $4.25 \mathrm{~m}$ by $4 \mathrm{~m}$ and $2.85 \mathrm{~m}$ by $2.15 \mathrm{~m}$ respectively.

\subsection{Features within and outside the palisade}

There were 54 pit features within the palisade enclosure that were not associated with any of the structures. They varied in their form and dimensions but all had fills with sand and silt components reflecting the composition of the natural subsoil. Pit scatters are a common occurrence on prehistoric sites and may have had a myriad of functions, including pits that had a structural component such as post holes, pits that were used for refuse or food processing, and pits that were excavated for ritual and symbolic reasons.
There was no obvious spatial patterning amongst these features that described the foundations of structures in plan. However, the features are undated and further features may have been lost through truncation; both of these effects confound the interpretation of the surviving features. However, it is possible that some of these were foundation pits for the posts in internal fences perhaps associated with stock handling, or they may have served as tethering posts for livestock, totems or even flagpoles.

One pit, 018 (Illus 55e), contained a large cache of cereal grain, and may have been used as a cooking pit in the MBA. Another pit to the east, 212 , contained a small piece of vitrified material which was probably intrusive. Other than these two, there was no artefactual evidence relating to any of these pits.

\subsection{Artefacts}

\subsubsection{Pottery}

\section{Melanie Johnson}

Just three small body sherds were recovered during the excavation in this area. All of the sherds were very abraded.

A single plain body sherd was found in Pit 385 within Structure 1A. A further plain body sherd was recovered from Pit 212 to the exterior of the palisade to the north-east. This feature lies within a small group of three pits, none of which are dated. The fabrics of both of these sherds are fine and lightly gritted, orange in colour, and $5-10 \mathrm{~mm}$ thick. The sherds are too few in number and are not sufficiently diagnostic to provide independent dating of the features and are likely to be background noise from domestic activities taking place on or near the site.

The third sherd was found during site cleaning and so is unstratified; this sherd is part of a concave neck and is decorated with parallel horizontal incised lines. The fabric is fine and sandy, and orange-brown in colour. This sherd is likely to be a fragment of EBA Beaker or Late Neolithic Impressed Ware. While unstratified, it does suggest some earlier prehistoric activity was taking place somewhere in the vicinity of the site and perhaps plough action has brought sherds into the topsoil from the fills of features. 


\subsubsection{Vitrified material}

Dawn McLaren

A small quantity of vitrified material (NMVR, $26.2 \mathrm{~g}$ ) was recovered from Area A features. Of this, $1.6 \mathrm{~g}$ was non-magnetic vitrified residue from Post Hole 495 in Structure 1A.

Three small fragments of magnetic, molten iron-rich vitrified material (UIS, 24.6g) were recovered from the fill of an isolated pit (227). No stratigraphic relationship between this pit and the palisade or internal structures could be detected and it is likely to be intrusive. Despite the small amount involved and its recovery from residual contexts, the presence of a small quantity of unclassified iron-rich slag does indicate that ironworking was taking place in the area but is unlikely to be contemporary with the date of the settlement due to the small quantities involved.

\subsection{Environmental evidence}

10.7.1 Calcined bone

Sue Anderson

This area produced a total of $45.2 \mathrm{~g}$ of bone distributed across 25 contexts. The majority was recovered from Structure $1 \mathrm{~A}$ and its annex $(30.15 \mathrm{~g})$ with the largest single deposit coming from the northern pit $(462 ; 26.2 \mathrm{~g})$. One fragment from the upper fill of the latter was submitted for radiocarbon dating (see Section 10.8 below). Where material was identifiable, all fragments were non-human and there was one possible antler fragment.

Fragments from Structure 2A totalled 14.05g, most of which came from Pit 005; none of this material was identifiable. The remaining pieces were recovered from one feature outside the palisade (018), five features inside the palisade $(003,124$,
$195,222,227)$ and the palisade slot $(058,153)$. All fragments were tiny and abraded.

\subsubsection{Charcoal \\ Michael Cressey}

Four species are represented in Area A (Table 20). Hazel is the most abundant (67\%), followed by oak $(22 \%)$. Both birch and willow are present in low amounts (5\%).

Eighteen fragments of oak $(7.7 \mathrm{~g})$ were recovered from the palisade, along with three fragments of hazel $(2.0 \mathrm{~g})$. Structure 1A samples from post holes contained oak (1.1g), hazel $(0.5 \mathrm{~g})$ and beech $(3.6 \mathrm{~g})$, and samples from the ring ditch fill (483) produced oak (1.8g) and hazel $(50.7 \mathrm{~g})$. Post holes in Structure $2 \mathrm{~A}$ contained oak $(1.7 \mathrm{~g})$ and hazel $(1.5 \mathrm{~g})$, and oak was also recovered from a charcoal layer $(0.5 \mathrm{~g})$. Other charcoal was collected from scattered post holes inside and outwith the palisaded area.

\subsubsection{Charred plant remains Mhairi Hastie}

Out of 144 samples assessed from this area, only nine contained any grains, and in all but one case, a pit (018), the quantity of grain present in each sample was extremely low, with only one or two very poorly preserved and abraded grains of barley (Hordeum sp.) being recovered.

The largest concentration of cereal grain was recovered from Pit 018 outside and to the north of the palisaded enclosure. No other large concentrations of grain were recovered. Small assemblages of cereal grain, seeds of hemp nettle (Galeopsis sp.) and hazelnut shell were present in the fills of post holes and pits concentrated primarily at the northern end of Structure 1A. All but two weed seeds were recovered from the fill of Pit 018 .

Table 20 Charcoal from Area A

\begin{tabular}{lccc} 
Species & No. of IDs & Weight $(\mathrm{g})$ & \% Frequency \\
Betula sp. & 15 & 9.5 & 5.6 \\
\hline Corylus avellana & 63 & 113.9 & 67.0 \\
\hline Quercus sp. & 99 & 37.8 & 22.2 \\
\hline Salix sp. & 6 & 8.7 & 5.1 \\
\hline Total & 183 & 169.9 & 100
\end{tabular}


The presence of charred plant remains, albeit in very small quantities, may feasibly indicate that some small-scale food processing was being carried out in the structure. Nevertheless, the very small quantity of plant remains recovered does not allow detailed discussion.

\section{Pit 018}

The fill of Pit 018 was found to contain a very large volume of burnt cereal grain, over 10,000 grains. The cereal assemblage consisted of almost pure grain which varied in preservation, although most grains were much abraded and this is reflected in the large quantity of small unidentifiable fragments of cereal grain that were present (Table 21). The bulk of the grain could only be identified as barley, yet where preservation was sufficient occasional grains of possible naked barley were identified. Fragments of barley rachis were also recovered, these being identified as the six-row variety. Weed seeds were present, along with the cereal grains, including persicaria, grasses, nipplewort, sedge and clubrush, the majority of which are typical weeds of cultivation. Large quantities of persicaria seeds were recovered from the sample; these are especially found in areas of moist arable soils and their presence along with other wet-loving seeds, such as sedge and clubrush, could indicate a lack of sufficient drainage in the arable fields.

Initial field results suggested that the fill of the pit had been burnt in situ so the pit was interpreted as a firepit, and it was suggested that the large quantity of grain had been accidentally burnt during corn-drying activities. However, soil morphological analysis of sediments from this feature (see Section 10.7.4, Ellis below) suggest that any in-situ burning, if it occurred, may have been masked by the process of rubefaction.

Considering the poor condition of the cereals it is suggested that the assemblage had probably been dumped into the pit. The extremely large quantity

Table 21 Composition of plant remains from Pit 018

\begin{tabular}{lllr} 
Latin name & Plant part & Common name & Quantity \\
Weed seeds & & & $78(\mathrm{e})$ \\
Polygonum persicariallapithifolium L. & Nutlet & Persicaria/pale persicaria & $6(\mathrm{e})$ \\
\hline Lapsana communis L. & Achene & Nipplewort & $6(\mathrm{e})$ \\
\hline cf Gramineae indet. (small) & Caryopsis & Small-grained grass & $12(\mathrm{e})$ \\
\hline Scripus spp. & Nutlet & Club-rush & $18(\mathrm{e})$ \\
\hline Carex spp. & Nutlet & Sedge & $12(\mathrm{e})$ \\
\hline Indeterminate & Seed & Indeterminate & $12(\mathrm{e})$ \\
Potentially economic species & & & \\
Corylus avellana L. & Nutshell & Hazel & 1 \\
\hline Cereal remains & & & $60(\mathrm{e})$ \\
\hline Triticum sp. & Caryopsis & Wheat & $76(\mathrm{e})$ \\
\hline Triticum/Hordeum sp. & Caryopsis & Wheat/barley & $11220(\mathrm{e})$ \\
\hline Hordeum var. nudum & Caryopsis & Naked barley & $3472(\mathrm{e})$ \\
\hline Hordeum sp. & Caryopsis & Barley & 6 \\
\hline cf Hordeum sp. & Caryopsis & Barley & $12(\mathrm{e})$ \\
\hline Hordeum sp.(6-row) & Internode & Six-row barley & $9876(\mathrm{e})$ \\
\hline cf Avena sp. & Caryopsis & Oat & ++++ \\
\hline Cereal indet. & Caryopsis & Indeterminate & \\
\hline Cereal indet. (small fragmentary bits) & Caryopsis & Indeterminate & \\
\hline & & & \\
\hline
\end{tabular}


of burnt grain recovered from the pit is unusual. The two main sources of burnt grain on prehistoric sites are: 1) grain stores destroyed by fire; and 2) grain burnt during food preparation or corn-drying. In this case it would seem most likely that the very high concentration of grain is more in keeping with the accidental burning of a grain store, rather than grain simply burnt during small-scale food preparation.

\subsubsection{Soil micromorphology \\ Clare Ellis}

\section{Structure 1A, Pit 462}

Four Kubiena samples $(<225>1-4)$ were taken through the fill of Pit 462 (Illus 55c). The lowermost fill (464) comprises poorly sorted silty fine sand with few grit-sized mineral grains and rock fragments. Much of the burnt amorphous organic content has been replaced by iron oxide; there are very few silt-sized and coarse charcoal fragments. Phosphate occurs throughout the organo-mineral material but is particularly concentrated around charcoal fragments and where concentrations of biogenic silica occur. There are a few rounded clasts rich in biogenic silica as well as very few rounded bone fragments. It is possible that some of the dark brown (in OIL) rounded clasts of fragmentary organic matter are the remnants of herbivore coprolites. The context has been disturbed by post-depositional bioturbation. There is a sharp and distinct boundary into the overlying poorly sorted silt, with few fine sand-sized grains and few grit-sized rock fragments (463). The basic composition varies slightly from granule to granule; some granules are dominated by reddish-brown burnt amorphous organic matter, others by pale yellowish-brown, phosphatic amorphous organic matter and others by silt-sized charcoal. Fine sand depleted in organic matter infills a large passage. Fragmentary phytoliths are relatively common but burnt, and unburnt fungal spores are rare. There are a very few minute fragments of bone.

At the base of the lowermost fill (464) are what appear to be redeposited clasts of natural sand turf (with internal graded bedding) that have been burnt. Clasts of more organic-rich turf with fragments of grass ash occur slightly higher up the profile, although bioturbation has resulted in the mixing of the ashy deposit. This deposit, with a relatively high phosphate, charcoal and phytolith content, as well as clasts composed of charcoal, iron oxide and mineral grains, is interpreted as coarse grass/straw that has been mixed with animal faecal matter. One possible explanation is that this deposit is the semi-burnt residue of animal bedding and/ or the faecal residues of herbivores such as cattle or horses. This material may have been accidentally burnt, or alternatively it may have been collected, dried and specifically utilised as a fuel. The presence of unburnt fungal spores is indicative of postdepositional decomposition.

The sharp boundary between Fills 464 and 463 demonstrates that there was relatively little mixing of the two contexts by soil fauna; this is perhaps due to a significant break between dumping episodes and/or the dumping of a considerable depth of 463, curtailing soil fauna activity below it in 464 . The overlying context, 463 , is dominated by burnt amorphous organic matter (presumably fuel residue) that has been juxtaposed with clasts of decomposed charred grasses (possible remnants of animal bedding). The original fabric of this deposit has been destroyed by post-depositional bioturbation.

\section{Structure 1A, south-east annex, Pit 422}

Six Kubiena samples $(<221>1-6)$ were taken through a sequence of fills within Pit 422 (Illus 55a). The lowermost context (483) comprises a poorly to moderately sorted sandy silt with frequent gritsized rock fragments. The fine material is dominated by dark reddish-brown organo-mineral silt (dark brown in OIL) with common silt-sized charcoal, with approximately $20 \%$ granules of charcoal and occasional yellow (phosphate) matter with frequent phytoliths and very few diatoms. There are frequent coarse sand-sized charcoal fragments and very few larger fragments. There is limited mixing of the two sediment types, although there are occasional granules which comprise both sediment types. There is a sharp, prominent wavy boundary between Fills 483 and 423 . The overlying context (423) is moderately sorted fine sandy silt with very few grit-sized rock fragments. This is characterised by dominant silt-sized charcoal set within an organomineral matrix in which the organic matter is extremely well decomposed. There are very few burnt fungal spores.

The dark reddish-brown fine organo-mineral material within Fill 483 is interpreted as a welldecomposed organic ash residue, probably originally 
derived from the burning of turf. The yellow microaggregates and granules with charcoal and frequent phytoliths are construed as residues of a grass-rich fuel, the high quantities of phosphate indicating that this material is likely to be the remnants of burnt animal dung. The presence of diatoms implies that the animals producing the dung were grazed-upon vegetation that was growing in reasonably damp conditions; the incorporation of mineral grains is likely to have occurred as the animals drank from muddy puddles (Courty et al 1989). The survival of a few larger fragments of charcoal may be due to the presence of the occasional root within the turf, although wood may have been used as an initial igniter, if turf was used as a fuel for a domestic fire. The occasional survival of the original fabric, visible in the juxtaposition of the two types of ash within a granule, is evidence of the sequential dumping of probable hearth waste prior to post-depositional bioturbation. The overlying context (423) is interpreted as an ashy deposit (also thought to be mostly derived from turf); the context has been subject to considerable postdepositional bioturbation. However, the presence of frequent mineral grains with orange (in OIL) coatings in the uppermost sample is indicative of the burning of turfs that either had a lower organic content (ie soil that was not so well developed or had been previously stripped) or to which more subsoil/natural was attached than those turfs which produced the ash lower in the deposit.

\section{External Pit 018}

Three Kubiena samples $(<41>1-3)$ were taken through the fills of Pit 018 (Illus 55e). The lowermost sampled context is the natural (002), moderately sorted fine sand with a few gritsized rock fragments. The fine organo-mineral component occurs as thin coatings to the mineral grains and rock fragments; this fine material is dark yellow-brown in PPL (plane polarised light) and orange in OIL. There are very few coarse charcoal fragments and very few phytoliths. The natural has been disturbed by post-depositional bioturbation. The basal fill (081) of the pit comprised a poorly to moderately sorted silt with a few fine sand grains with an increasing charcoal content from the base upwards. The boundary between 081 and 019 is diffuse and faint. Context 019 is poorly sorted silty fine sand dominated by burnt amorphous organic matter, with very few silt-sized and coarse charcoal fragments. It contains very few burnt fungal spores, phytoliths and rounded bone fragments. Intensive bioturbation has resulted in both of the pit contexts exhibiting crumb microstructures.

The natural fine sand (002) shows segregation of iron oxides within thin coatings to many of the iron-rich rock fragments and mineral grains; the same is observed in $002<897>$. The former deposit was interpreted in the field as being heataffected, but given the intensity of iron segregation, the segregation is more likely to be a result of natural rubefaction rather than heat induced; any effects from an in-situ fire would be masked by this natural phenomenon. The overlying deposit (081) is dominated by weathered charcoal, with a few mineral clasts incorporated by soil fauna. The context has been extensively disturbed by soil fauna, but comprises partially combusted organic matter including woody species. The amorphous organic content of C019 appears to have been largely replaced by iron oxides. Together with low quantities of charcoal and minimal biogenic silica this context is thought to include the remnants of a dirty natural and/or mineral-based turf mixed with smaller quantities of wood and/or herbaceous ash.

\subsection{Radiocarbon dating}

The environmental assemblage, in terms of radiocarbon dating, from this area was very poor in quantity, condition and range of taxa, with much of the material derived from oak, and because of that species' longevity it was excluded from further analysis. Many of the deposits within features were sterile, limiting the choice of what could be targeted for dating. Fourteen dates were obtained from charred barley grains, charcoal from hazel, alder and birch and one date from a large mammal bone (Table 22; Illus 56). Nine dates were returned from Structure 1A, one from Structure 2A, one from Structure 4A, one from the palisade trench and two from an external pit. The majority of dates suggest an occupation period in the EIA, although MBA activity is indicated from the date range 1624-1495 cal вс (95\% probability; UBA-13409).

Pit 018 appears to pre-date the palisade, having two MBA dates which are not statistically 


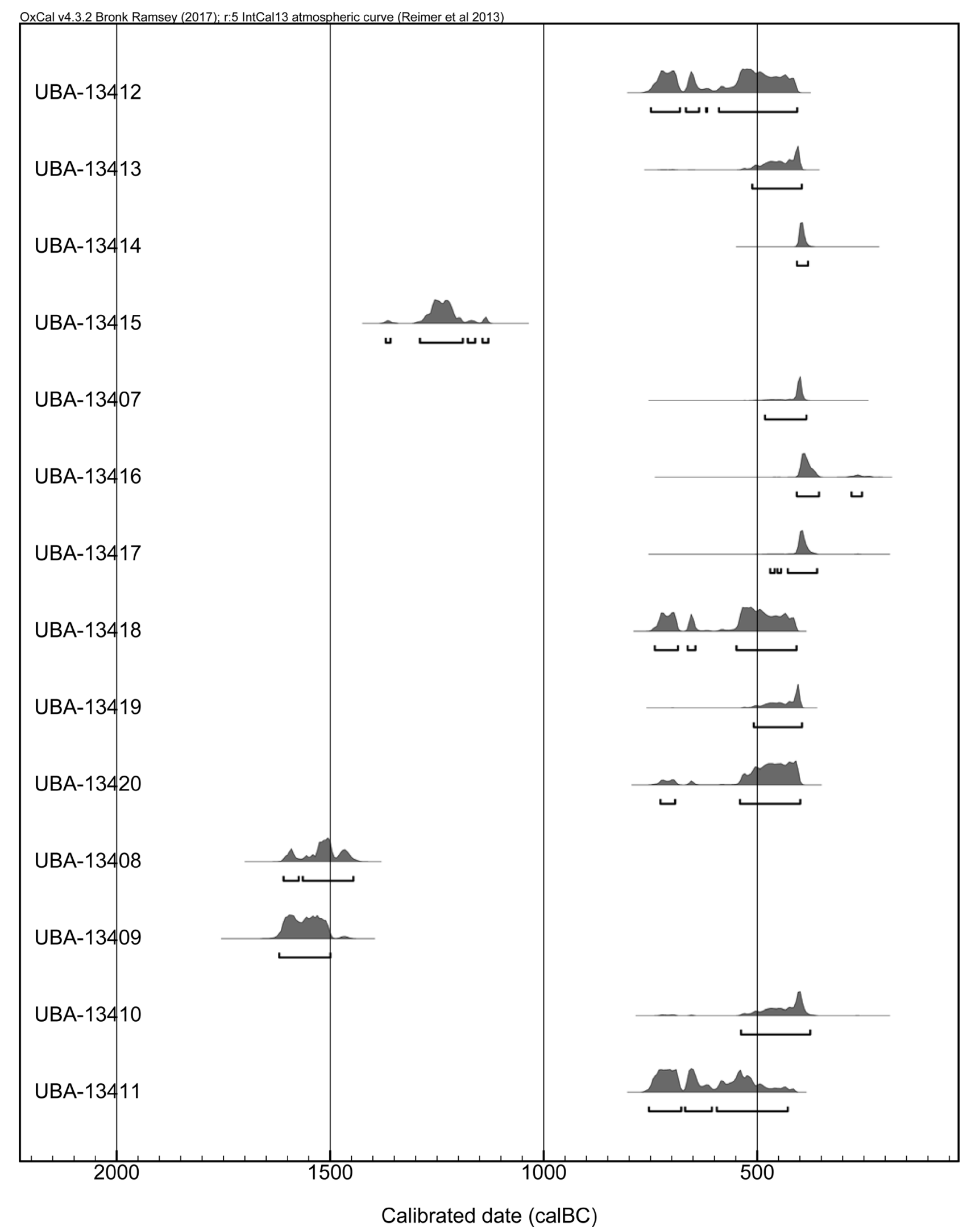

Illus 56 Radiocarbon dates, Area A 
Table 22 Radiocarbon dates, Area A. Calibration was conducted using OxCal v4.1.7, using the IntCal09 calibration curve

\begin{tabular}{|c|c|c|c|c|c|}
\hline Lab no. & Material & Context description & Date вP & $95 \%$ probability & $\begin{array}{l}\delta^{13} \mathrm{C} \\
\% 0\end{array}$ \\
\hline \multicolumn{6}{|l|}{ Str $1 A$} \\
\hline UBA-13412 & Hazel charcoal & Primary fill of Pit 324 & $2441 \pm 25$ & 749-408 вс & -26.1 \\
\hline UBA-13413 & Hazel charcoal & Fill of Pit 385 & $2382 \pm 20$ & $512-397$ вс & -28.8 \\
\hline UBA-13414 & Hazel charcoal & Fill of Pit 385 & $2331 \pm 19$ & $406-385$ вс & -30.3 \\
\hline UBA-13415 & Alder charcoal & Fill of Pit 385 & $3001 \pm 19$ & $1370-1132$ вс & -26.9 \\
\hline UBA-13407 & Large mammal & Upper fill of Pit 462 & $2355 \pm 20$ & $505-387$ вс & -28.0 \\
\hline UBA-13416 & Naked barley & Upper fill of Pit 462 & $2307 \pm 27$ & $407-236$ вс & -23.8 \\
\hline UBA-13417 & Naked barley & Upper fill of Pit 462 & $2330 \pm 26$ & $483-263$ вс & -26.6 \\
\hline UBA-13418 & Hazel charcoal & Upper fill of Pit 462 & $2437 \pm 18$ & $742-409$ вс & -26.5 \\
\hline UBA-13419 & Hazel charcoal & Upper fill of Pit 462 & $2378 \pm 18$ & $511-396$ вс & -25.5 \\
\hline \multicolumn{6}{|l|}{ Str $2 A$} \\
\hline UBA-13420 & Hazel charcoal & Upper fill of Pit 005 & $2402 \pm 26$ & $726-399$ вс & -24.3 \\
\hline \multicolumn{6}{|c|}{ External feature } \\
\hline UBA-13408 & Barley indet. & Primary fill of Pit 018 & $3244 \pm 25$ & $1607-1446$ вс & -27.7 \\
\hline UBA-13409 & Barley indet. & Primary fill of Pit 018 & $3277 \pm 27$ & $1624-1495$ вс & -29.8 \\
\hline \multicolumn{6}{|l|}{$\operatorname{Str} 4 \mathrm{~A}$} \\
\hline UBA-13410 & Hazel charcoal & Fill of Post Hole 200 & $2359 \pm 33$ & 701-381 вс & -30.9 \\
\hline \multicolumn{6}{|c|}{ Palisade post hole } \\
\hline UBA-13411 & Birch charcoal & Fill of Post Hole 258 & $2459 \pm 19$ & $753-414$ вС & -25.6 \\
\hline
\end{tabular}

significantly different. These can be combined to provide an average date range of $1615-1470 \mathrm{cal}$ BC.

No dateable material was retrieved from the palisade deposits. Therefore material from Pit 258 that cut the palisade was used, which returned a date of 753-414 cal вс (95\% probability; UBA-13411). However, there are a number of caveats associated with this date. The pit may have been the remains of a post hole that cut the palisade, and therefore is stratigraphically later than the palisade. Alternatively, the feature may have been a foundation for a palisade post or a later replacement post during the construction or use of the palisade, or the position of Post Hole 258 may be entirely coincidental and unrelated to the palisade construction and would therefore post-date the palisade. The charcoal could have become incorporated within the fill of the post hole either when the packing deposit was shovelled into the post hole to secure the post, thus dating the construction event of the post hole, or anytime afterwards through the action of bioturbation or other physical means such as modern ploughing.

Of the five dates from the lower deposit of Pit 462 in Structure 1A, two were returned from naked barley grains (UBA-13416 and UBA-13417). Cereal grains will generally deteriorate more quickly when exposed to the elements than wood or bone, so those which become incorporated into feature fills are unlikely to have been lying on the ground surface for very long. However, as the dated material is light and relatively small it is possible that it became incorporated into the fill through taphonomic processes after the pit was filled with deposits.

Three dates were obtained from charcoal retrieved from Pit 385 in Structure 1A, one of which (UBA-13415) was an outlier. The other two were consistent to $95 \%$ confidence level returned from a chi-squared test, and the outlier is assumed to be 
residual given that the dates from the palisade and houses are consistent within a reasonably narrow date range. But, as with the dates returned from Post Holes 200 and 005, there was no evidence of in-situ burning, thus suggesting the charcoal was intrusive, and it could have become incorporated into the post holes during the emplacement of the post within the hole, or during the structure's lifetime as the material sifted its way down through the loosened earth, or even after the post had rotted away or was robbed out. Generally, however, the dates are consistent with a settlement occupied in the middle of the first millennium $\mathrm{BC}$, although the evidence is mixed and the taphonomic security of dated samples must be taken into consideration.

The earliest date from the site indicates MBA activity (Pit 018 ), but the majority of the dates indicate an EIA phase of occupation. With the exception of Pit 018, the pits both within and outside the palisade have not been dated and may relate to activities spanning the period from the MBA to the EIA, but equally could fall outside this date range.

\subsection{Discussion}

\subsubsection{Phasing}

The only stratigraphically related features on site were the intercutting post holes in Structure 1A: $413 / 415,485 / 477$ and 343/341, the post holes that cut the palisade (eg 258) and possibly, because of their proximity, 373/371, 331/336 and 334. These are likely to represent running repairs to degraded posts within that structure's lifetime. Aside from these repairs, the fact that all the features physically respect each other suggests a planned layout and the probability that the entire site was contemporaneous. The planned nature of the site is also reflected in the orientation of the entrances to the houses and their alignment to and equal distances from the corresponding entrances in the palisade.

Whether Structures 1A and 2A were in use at the same time largely depends on the interpretation of the form of their roofs, as the radiocarbon date ranges for both structures overlap. If the eaves from the roofs projected out and down to ground level then the structures could not be contemporary as the space between them would have been too narrow to accommodate the projecting eaves.
There was no evidence, in the form of drip-gullies or foundation slots for the eaves, to intimate that the roofs projected to ground level. If, however, the eaves of the structures were cut short at the height of the external curtain wall, then the two structures could have stood at the same time, separated by a sheltered corridor.

The radiocarbon dates returned from this site indicate an EIA period of occupation. However, dates returned from Pit 018 indicate MBA activity. Pottery recovered from unstratified contexts was identified as EBA Beaker or Late Neolithic Impressed Ware and also attests to earlier phases of activity within the area.

\subsubsection{Architectural features of the structures}

There are both differences and similarities in the architecture of Structures $1 \mathrm{~A}$ and $2 \mathrm{~A}$ when compared with the MBA/LBA structures at Blackford. The necessity for ring grooves for the foundation of the outer walls has been overcome here by constructing a contiguous post-built wall, as indicated by the proximity of the post holes of the post hole ring in Structure 1A. Given the close spacing of the post holes it is probable that the walls were formed as a continuous woven basket, broken only at the entrance directly utilising the posts within the post ring. The post holes on the eastern side of Structure 1A had been replaced by a small section of a foundation slot (481), presumably into which a wall had been secured. A similar argument could be made for Structure 2A, with linear features 573 and 577 representing the remains of a wall foundation. There was no evidence for post holes within its cut, nor chocking stones for securing either posts or planks. It may be that the four pits $(322,324,489$ and 498) offered extra load-bearing potential at this juncture.

The evidence for ring ditches and their function has been discussed above (Section 4). However, where internal pits survived in the Area A structures, they were shallow and did not occupy proportionately as much of the internal floor space as those found in the MBA structures. Indeed, in Structure $1 \mathrm{~A}$ a pit was excavated within an annex to the building, and if it is accepted that Grooves 497 and 481 were foundations for a wall then this pit may also have been covered by an extension of the 
structure's roof. Finally, the size of the structures of upwards of $14 \mathrm{~m}$ in diameter made these the biggest structures identified during the entire excavation. The possible post pad (492/491) and the arc of pits on the eastern quadrant of the house $(322,324,489$ and 479) may also have contained posts to increase roof support for this large building.

No parallels have been found for these structures at other Scottish sites. Perhaps the closest parallels are the stake-wall roundhouses found in some parts of south-west England and Wales, particularly an example at Frilford, Oxfordshire (Harding 2009: fig 12.5). However, all of these structures are less than $10 \mathrm{~m}$ in diameter, and it has been suggested that this type of structure could not have supported a roof if it was more than $7.5 \mathrm{~m}$ in diameter (Coles 1973: 59). Whether this applies to the stronger posts which must have been employed at Blackford is uncertain. However, it seems unlikely that Structure 1A, at least, was simply a stock enclosure, as Harding proposes for Frilford (Harding 2009: 70), since a corral would not require annexes and is unlikely to have had concentric ring ditches.

As well as differences, Structures $1 \mathrm{~A}$ and $2 \mathrm{~A}$ show similarities with the earlier MBA structures. Their general plan is circular and they were post-built. The entrance of Structure 1A was orientated to the south-east, the same orientation adopted by the builders of the MBA structures, where determined. However, the orientation of the entrance to Structure 2A, as defined by opposing Features 005 and 579, appears to be to the north-west. Although almost all of the other structures at Blackford have entrances to the south-east, the entrance for Structure 2A is orientated towards the entrance through the palisade enclosure, suggesting that this was a more important factor than those driving a south-east entrance bias.

Structures $3 \mathrm{~A}$ and $4 \mathrm{~A}$ were interpreted as structures based on the spatial arrangement of the post holes and their similarity in size and form. Comparable structures have been recorded at Little Woodbury (Ellison \& Drewett 1971: 85) and at Dryburn Bridge (Dunwell 2007). Early interpretation by Bersu (1940) suggested they were raised granary stores. The post holes that were analysed for charred grain $(50 \%$ in total) did not contain any cereal grain, further only one post hole of Structure 2A (200) contained a small amount of charcoal. During excavation there was no indication of a destruction layer sealing the structures. There is no evidence therefore that these structures burnt down, and the possibility exists that they were emptied of grain on abandonment of the site. Other explanations for the function of these rectangular structures have included small buildings, animal pens, watchtowers, exposure platforms for the excarnation of the dead, and porches relating to circular structures the rest of which have not survived (Ellison \& Drewett 1971; Guilbert 1975; Guilbert 1981; Kendrick 1995: 64). The possibility that these are remnants of earlier structures, although not completely dismissible, is thought in this case to be unlikely. Had they been porch structures, they were not orientated to the south-east as are those of the majority of structures across the entire excavation. There was no evidence of the rest of such putative circular structures or which direction they may have been orientated. The possibility that they were watchtowers associated with a defended settlement in a time of internecine strife is supported by their proximity to the two points of egress through the palisade. However, the rectangular structures are also proximally close to Structures $1 \mathrm{~A}$ and $2 \mathrm{~A}$, and may in some way be related to activities associated with those houses, such as storage or animal pens.

The palisade may have filled a single or multiple purposes. Depending on its height, which cannot be estimated from its foundation trench because the original depth of the trench cannot be ascertained due to truncation, the palisade may have served as a defensive structure against marauders or against the elements, for stock control purposes, as well as having symbolic and status elements, particularly if it was designed to be an imposing structure set atop a hill.

There was no evidence to explain why an elliptical palisade was constructed, rather than a circular or rectangular one. There were no obstacles to the west such as boulders, protruding bedrock or indications of dense tree cover, surviving as tree boles that could account for the tapering of the palisade at this point. Whether there were physical obstacles at the time of construction which have subsequently been removed or have eroded away is unknown. If it were oval in form, such as the enclosures at Dryburn Bridge (Dunwell 2007) and at Braehead (Ellis 2007), then its enclosed space would be greater, as would the ergonomics of building it and the requirement for raw materials. One possibility is that the shape 
was dictated by the activity within the enclosure: a cluster of pits to the north-east of Structure 1A was physically respected by the palisade, and although there is a lesser cluster of pits to the north-west of Structure 2A, they are closer to the structure, therefore less space needed to be enclosed.

The exact height of the palisade cannot be predicted from the depth of its foundation trench as this feature has undergone horizontal truncation. However, one would expect that if the purpose of the palisade was defensive then its height would need to be substantial. If its purpose was defensive and its height restricted viewing over the top of the structure, then a raised parapet running along the inside of the palisade would have been necessary. The width and depth of the foundation trench, even after truncation, was big enough for it to have held sturdy posts of $c 0.4 \mathrm{~m}$ diameter, larger than modern telegraph poles, and planks rather than a thin wall of wattle construction. If the construction of the palisade was a direct response to offensive action then the two four-post structures, Structures $3 \mathrm{~A}$ and $4 \mathrm{~A}$, may be interpreted as guard towers, as both are placed adjacent to entrances.

The palisade appeared to have incorporated both round and tapered posts and probably planks in its construction. Although there was no direct evidence of the material used, eg waterlogged wood remains within post holes, there is indirect evidence of the extensive use of oak as compared to other species of wood represented across the site. A palisade of plankand post-built construction has been suggested for the later prehistoric enclosure at Braehead (Ellis 2007). Material from one of the post holes of the palisade (258) returned a radiocarbon date range of 753-414 cal BC, similar to that returned from the remnants of an oak plank from the Braehead enclosure, 800-480 cal BC.

There were two breaks representing the palisade's entrances; one to the south-east the other to the north-west, which were defined by the palisade's terminal ends and associated post holes. There was no direct evidence for a gated structure at either of the two proposed egresses; the post holes (165 and 060) could equally have functioned as straining posts for the palisade. Assuming that the egresses were gated, they were not elaborate like those at Braehead (Ellis 2007: 247). The apparent strategic placement of the two boulders outside the south-east entrance may have had a function to do with access through the entrance, or they may have been markers or ritual statements related to the enclosure and its occupants.

The palisade foundation slot would have been excavated first: the reason for a continuous trench rather than a series of contiguous post holes was that the ground-breaking only had to be done once (Hansen 1959; Harding 1974) and a continuous foundation trench allows more leeway for the subsequent placing of posts. On completion of the excavation, or part thereof, the upright posts and planks were secured into the bottom of the trench and the trench backfilled with the excavated material, including the stones, some of which appear to have been used as edge-set chocking stones. The use of stone packing material has been noted at Braehead (Ellis 2007), Dryburn Bridge (Dunwell 2007) and at many other similar sites.

There were a number of pit features across the site. They broadly fall into three groupings, those to the north-east of Structure 1A, north-west of Structure $2 \mathrm{~A}$ and those outside the palisade. With the exception of Feature 018 , which is much earlier in date, they remain undated. Similarly, other than the obvious proximity of pits to Structures $1 \mathrm{~A}$ and $2 \mathrm{~A}$, there was nothing in their spatial arrangement indicative of structures or functions. The functions of these pits, ubiquitous on prehistoric sites, have been interpreted in many ways, including as post holes for fences and internal divisions, tethering posts for animals, flag or totem poles and refuse and latrine pits. Storage pits are another explanation and Pit 018 with its cache of grain may be such an example.

\subsubsection{Finds distribution and taphonomy (IIlus 57)}

The artefact assemblage was extremely poor and does not allow for a detailed analysis. The unstratified possible EBA Beaker or Late Neolithic Impressed Ware testifies to earlier prehistoric activity within the vicinity of the excavation.

Pottery was recovered from the fill of Pit 385, and it is perhaps not a surprise in a domestic setting that some pottery was caught in what might be considered an artefact trap. What is perhaps more surprising is the lack of pottery across the structures within Area A. There are a number of explanations for this phenomenon. First, the occupants were not using much pottery, either out of preference or for 
economic reasons, ie lack of available raw material or limited access to finished products. Although pottery is ideally suited for use as cooking vessels, it is not needed for eating or serving, where wooden, leather or basketry vessels are adequate. The lack of pottery may then just be a reflection of the original artefact assemblage and/or differential survival rates within the assemblage. Pottery sherds may have been present within other internal features of the circular structures, which have now been entirely removed, along with any pottery sherds, by subsequent ploughing. Or the sources of clay had over the thousand years of occupation at Blackford become depleted, which seems unlikely given the landscape.

The three small amorphous fragments of unclassified iron-rich slag that were recovered from Pit 227 may be intrusive material, as there was no other evidence of metalworking on site; Feature 227 was extremely truncated, only measuring $0.2 \mathrm{~m}$ in diameter by $0.02 \mathrm{~m}$ deep.

\subsubsection{Economy and production}

There is little evidence relating to economy and production. The charred cereal and artefact assemblage is poor. Pit 018 contained the highest concentration of charred grain and weed seeds. The combined paired dates from this pit returned a MBA radiocarbon age range of 1615-1470 cal BC. Analysis of the soil micromorphology suggests that if there had been any in-situ burning within the pit, it had been masked by the process of rubefaction. The upper deposit of Pit 018 contained partially combusted organic matter and charcoal, and coupled

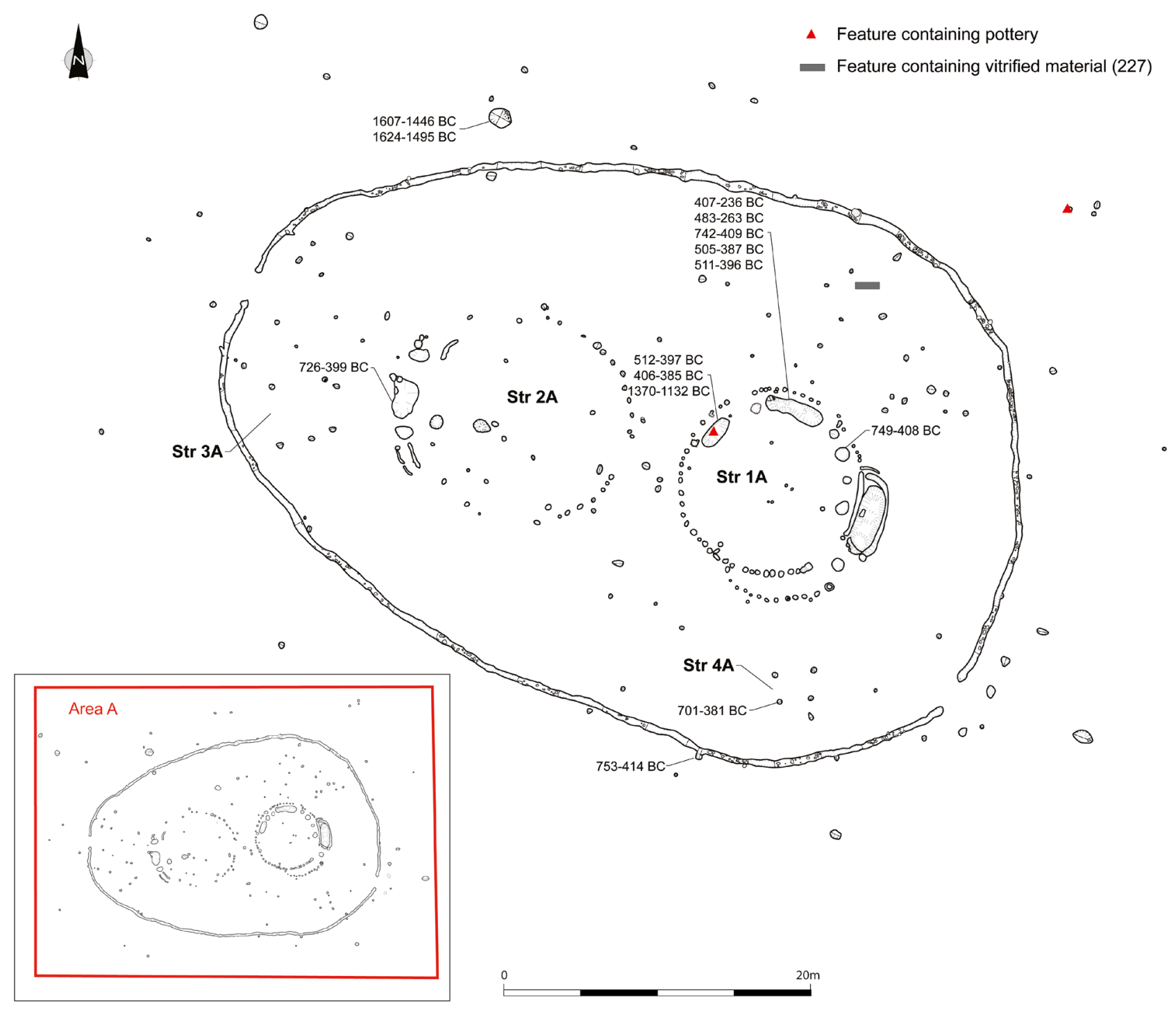

Illus 57 Finds and dating distribution plan, Area A 
with the presence of charred grain suggests that the cereal was being processed through heat, probably cooking, and became burnt and subsequently dumped into the pit during the process.

The pit contained weed seeds that are associated with crop husbandry and that thrived in moist conditions (see Hastie, Section 10.7.3 above). Of particular interest was the presence of nipplewort (Lapsana communis). It has been suggested that this plant is indicative of long fallow cultivation because of its shade tolerance and ability to grow in shaded cultivation plots within woodland (Whittle 1997), while others have suggested that the shade was provided by hedgerows enclosing the cultivation plots (Bogaard 2004), and yet others that the shade may have been cast by stands of trees or single trees left standing within small cultivation plots (Bakels 1978, cited in Milisauskas \& Kruk 1989). The degree of deforestation during the MBA at Blackford is not known, and either scenario, of cultivation within woodland clearings or cultivation in plots bounded by shade-producing hedges, is possible. Although there was no evidence of field boundaries that might represent hedgerows within Area A, in Areas D and $\mathrm{H}$ there were linear features that, because of their sinuous and irregular nature, may qualify as the remains of such boundaries. The other weed seeds were indicative of poorly drained soils. Hastie (10.7.3 above) suggests that this may be due to poorly drained arable fields, however, field observation suggests that the subsoil across the site with its high concentration of gravels was largely free draining. Only in some low-lying areas such as Area $\mathrm{D}$ were modern field drains in use. It is possible that the crops were either grown in the small valleys between the drumlins, or possibly in woodland clearances, both qualifying as wetter areas. Both naked and hulled barley were also present. Naked barley was a staple cultivar in Scotland from the Neolithic to the Iron Age, and its presence within a MBA context is no surprise; however, hulled barley was a later introduction within the Scottish context more usually associated with the LBA and the IA (Iron Age) rather than the MBA (Dickson \& Dickson 2000).

Naked barley was still being cultivated during the EIA period at 407-263 BC (UBA-13416 and UBA-13417). The small quantity of cereal grains recovered from structural features were all from
Structure 1A, and were concentrated in the northern sector of the structure, in Features 363, 385, 462, along with a summer-flowering European annual weed, hemp nettle (Galeopsis sp.). The latter, while a typical weed plant in cereal crops, may also have been deliberately collected, as the seeds have some medicinal properties and the stem is useful for the manufacture of rope and textile. The skewed northerly distribution of cereal grains may have derived from the putative animal bedding that was burnt in situ (see soil micromorphology, Section 10.7.4 above).

The lack of chaff in either the MBA or EIA assemblages suggests that the processing of the harvested ears of grain was not undertaken within the structures, although the lack of chaff is a common feature of archaeobotanical assemblages across Scotland in these periods, and the distribution within the pits in Structure 1A is likely to be the result of grains that became charred during the food processing stage and were swept in or otherwise incorporated within these features. The presence of such a small amount of grain within these pits is more likely related to accidental rather than deliberate deposition.

The poor artefact assemblage does not allow detailed interpretation of either the manufacturing process or the distribution of the finds. Pottery was recovered from only two contexts: Pit 385 in Structure 1A and a small external pit, 212, both deposits likely to be the result of accidental rather than structured deposition. The material in Pit 385 may have become deposited during floor-sweeping episodes.

Evidence for ironworking was found in the form of three small amorphous fragments of unclassified iron-rich slag which were recovered from Pit 227. The low quantity and insecure context within a very truncated feature, coupled with the lack of evidence of iron industry, could mean the material is simply intrusive and may not be contemporary with the site.

\subsubsection{Structure use}

As with other areas, when addressing the function of Structures $1 \mathrm{~A}$ and $2 \mathrm{~A}$ it cannot be assumed that the presence of a ring of post holes means that the posts supported a ring-beam and other elements of a 
roof. If the structures were unroofed then a plausible explanation of function could be as animal corrals. However, it seems unlikely that an animal corral would need further protection from an extensive palisade, or external pits, or a post-built annex like Structure 1A. It is argued that these elements are indicative of a structure designed primarily for human use, and by extension, although the features are considerably more truncated, so was Structure 2A. The lack of artefactual evidence from the structures precludes analysis as to whether the structures were used as houses, workshops or both. The opposing, seemingly planned, orientations of the house entrances to the south-east and northwest, which also align with the south-east and north-west entrances of the palisade, raises questions as to whether the houses had ritualistic or other meaningful uses.

The form and depth of the internal pits within Structure $1 \mathrm{~A}$ are suggestive of wear caused by animals and/or the repeated cleaning-out of used animal bedding and excrement. The external pit (422) of Structure 1A also displayed three distinctive wear patterns at the base of its cut that could also have resulted from stalling animals. The soil micromorphology analysis offers some clues regarding the function of these pits. The lower fill (464) of Pit 462 has been interpreted by Ellis as burnt material composed of coarse grass/straw mixed with faecal residues of herbivores such as cattle and horses. Ellis offers two possible explanations: either the material was animal bedding that had burnt in situ in the bottom of the pit, or the material was collected, dried and used as fuel, the burnt end-product of which was deposited within the pit.

If the material was burnt in situ it would likely have been associated with a hearth. The pit was not interpreted as a hearth because of its proximity to the wall of the structure, its position at the back of the house and the fact that there was no evidence of burnt subsoil. Ellis notes a sharp boundary between the lower fill, 464, and the upper fill, 463, suggesting a two-stage depositional event rather than a period of sequential dumping as one may expect if these fills derived from regularly cleaning out a hearth.

The lower fill (483) of Pit 422 contained ash residue derived from the burning of turfs and a high concentration of phosphate. Furthermore, this material appears to have been sequentially dumped, something that Ellis interprets as the dumping of hearth material. This deposit may represent the build-up of animal dung and bedding which was periodically covered with ash from the fire for sanitary reasons.

The balance of evidence suggests that both the external and internal pits in Structure 1A could have been used as animal stalls.

\subsubsection{Site abandonment}

There were few intercutting features or other evidence for major re-structuring or rebuilding within the area suggestive of a single phase of occupation followed by abandonment. The soil micromorphology analysis indicates that turfs were burnt and incorporated into the upper fill of Pit 422. It seems unlikely that these turfs were used as fuel, the waste of which was used to fill a pit. An alternative explanation would be that this material derived from the roof when the building burnt down. However, there was no extensive layer that was interpreted in the field as a destruction layer, although both the upper fills of Pits 462 and 385 appeared to be the same as a charcoal-rich deposit that masked both these features and the intervening post holes pre-excavation. It may be that this deposit was the vestigial remains of a destruction layer, some of which had been truncated away.

The general lack of evidence for in-situ burning across the whole of the site lends support to the hypothesis that the site was abandoned but not burnt down. 